\title{
田 \\ Contaminants in Unionid Mussels from the Confluence of the Mississippi and Illinois Rivers
}

Joan Esarey, David J. Soucek, Jeffrey M. Levengood, Robert J. Hudson, Wade Wimer, Richard S. Halbrook 


\section{I L L L I N O I I S}

Institute for Natural Resource Sustainability, William Shilts, Executive Director

Illinois Natural History Survey

Brian D. Anderson, Director

I-Building

1816 South Oak Street

Champaign, Illinois 61820

217-333-6880

Citation:

Esarey, J., D.J. Soucek, J.M. Levengood, R.J. Robertson, W. Wimer, and R.S. Halbrook. 2008.

Contaminants in unionid mussels from the confluence of the Mississippi and Illinois rivers. Illinois Natural History Survey Bulletin 38(5):197-214.

Editor: Charles Warwick

US ISSN 0073-4918

US ISBN 1-882932-19-6

Printed by authority of the University of Illinois (C) 2008

$\mathrm{P} 0217729-.75 \mathrm{M}-11-08$

Printed with soy ink on recycled and recyclable paper.

The University of Illinois will not engage in discrimination or harassment against any person because of race, color, religion, national origin, ancestry, age, marital status, disability, sexual orientation including gender identity, unfavorable discharge from the military or status as a protected veteran and will comply with all federal and state nondiscrimination, equal opportunity and affirmative action laws, orders and regulations. This nondiscrimination policy applies to admissions, employment, access to and treatment in University programs and activities.

University complaint and grievance procedures provide employees and students with the means for the resolution of complaints that allege a violation of this Statement. Inquiries or complaints may be addressed to the Director and Assistant Chancellor, Office of Equal Opportunity and Access, 601 East John Street, Swanlund Administration Building, (217) 333-0885, fax (217) 244-9136, TTY (217) 244-9850 or the Associate Provost and Director, Academic Human Resources, Henry Administration Building, (217) 333-6747, fax (217) 244-5584. For other University of Illinois information, contact University Directory Assistance at 333-1000. 


\section{Contaminants in Unionid Mussels from the Confluence of the Mississippi and Illinois Rivers}

Joan Esarey ${ }^{1}$, David J. Soucek ${ }^{1}$, Jeffrey M. Levengood ${ }^{1}$, Robert J. Hudson ${ }^{2}$, Wade Wimer ${ }^{2}$, Richard S. Halbrook ${ }^{3}$

1. Illinois Natural History Survey

2. University of Illinois

3. Southern Illinois University

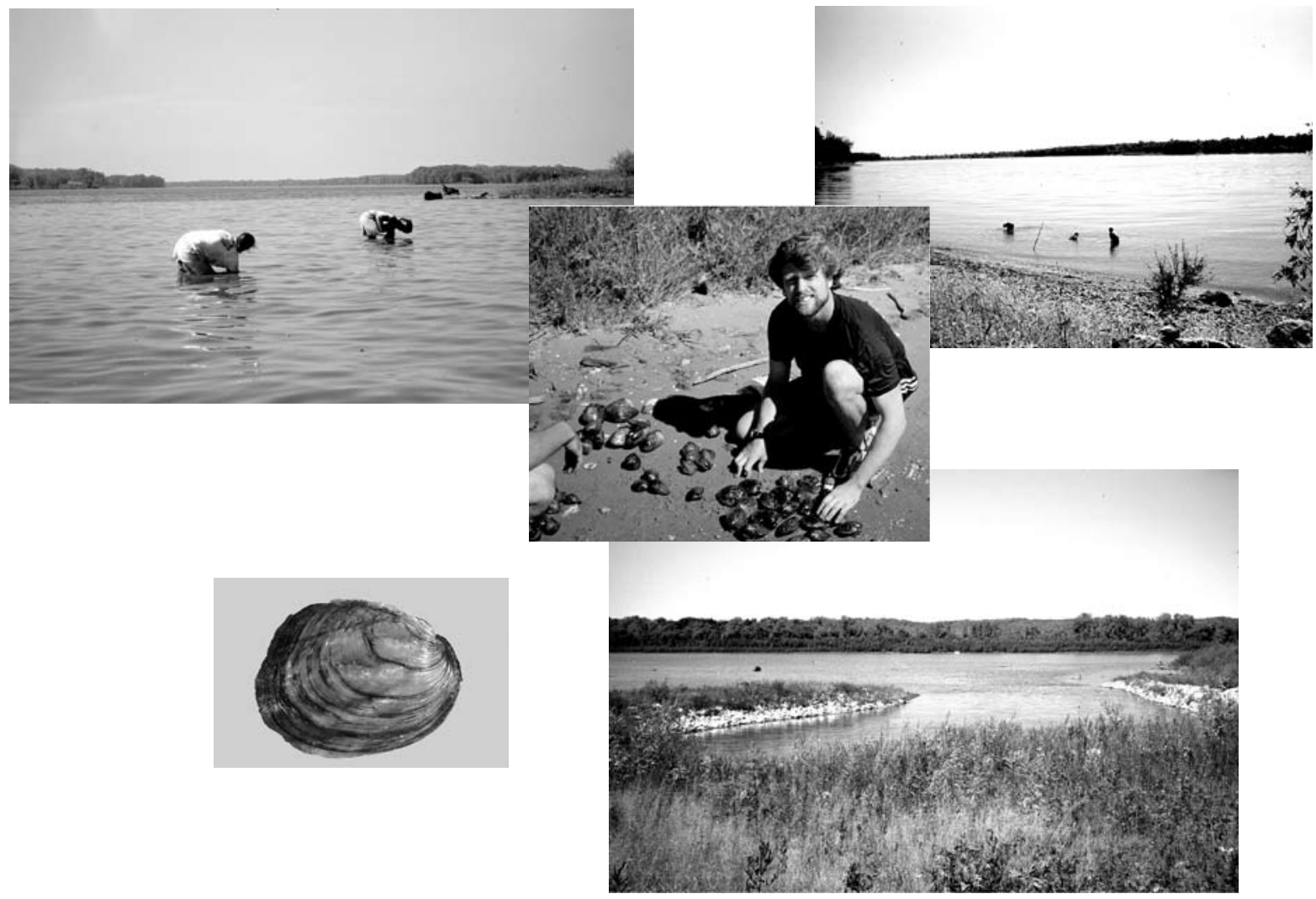

Correspondence to:

Jeffrey M. Levengood

Division of Ecology and Conservation Science

Illinois Natural History Survey

1816 S. Oak St.

Champaign, IL 61820

271-333-6767

jleven@inhs.uiuc.edu 


\section{CONTENTS}

Acknowledgements..................... ii

Abstract...................................... 197

Introduction. . . . . . . . . . . . . . . . . . . . . . . . . . . . . 197

Methods............................................199

Mussels ......................................199

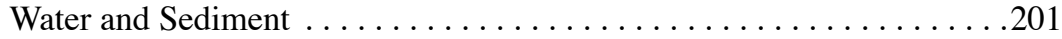

Statistical Comparisons. . . . . . . . . . . . . . . . . . . . . . . 202

Results.........................................203

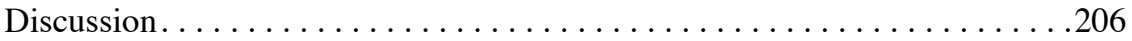

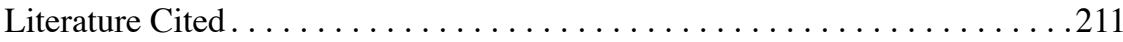

\section{ACKNOWLEDGMENTS}

Special thanks to the following: John Tucker and Charlie Warwick, Illinois Natural History Survey; Loretta Skowron, Mary LeFaivre, and Daniel Webb, Illinois State Water Survey; Danny Brown and Sandra Rackers, Missouri Department of Conservation; Richard Sparks, National Great Rivers Research and Education Center (NGRREC); Jon Talbott, Illinois Sustainable Technology Center; Rudiger Laufhutte and Marie Keel, University of Illinois at Urbana-Champaign Microanalytical Laboratory; Gary Dreher, Illinois State Geological Survey. This project was funded by the NGRREC. 


\section{ABSTRACT}

Unionid mussels were collected from three mussel beds near the confluence of the Mississippi and Illinois rivers in 2003 to evaluate concentrations of selected elements and organic compounds in three abundant species and to preliminarily investigate the relative contribution of these waterways to observed contaminant burdens. Copper $(\mathrm{Cu})$, selenium $(\mathrm{Se})$, and zinc $(\mathrm{Zn})$ concentrations were higher and lead $(\mathrm{Pb})$ concentrations were lower in Amblema plicata collected downstream of the confluence than in those collected upstream. Mean concentrations of nickel (Ni), total mercury $(\mathrm{Hg})$, methylmercury $(\mathrm{MeHg}), \mathrm{Pb}$, and $\mathrm{Zn}$ varied by species. Concentrations of cadmium $(\mathrm{Cd})$ decreased with age in A. plicata from two of three sites. Tissue concentrations of some elements, e.g., arsenic (As), $\mathrm{Cd}, \mathrm{Cu}, \mathrm{Pb}, \mathrm{Se}$, and $\mathrm{Zn}$, were similar to or higher than those previously reported for unionid mussels from areas of contaminated sediment. Concentrations of $\mathrm{Cd}, \mathrm{Cu}$, and $\mathrm{Zn}$ in A. plicata were comparable to those collected from the Mississippi River approximately 450 and $900 \mathrm{~km}$ upstream from our study sites (Naimo et al. 1992). Although total $\mathrm{Hg}$ concentrations we observed were an order of magnitude lower than in that study, $\mathrm{MeHg}$ concentrations were above those associated with reductions in soft tissue mass in a study of Elliptio complanata (Salazar et al. 1995). A number of polychlorinated biphenyl (PCB) congeners were detected in A. plicata tissues, with $85 \%$ of detections occurring in mussels from downstream of the confluence. Concentrations of individual PCB congeners were $\leq 33 \mathrm{ng} / \mathrm{g}$ ww and the maximum summed PCB congener concentration was $100.2 \mathrm{ng} / \mathrm{g}$ ww. Although few persistent pesticides were detected, $\beta$-hexachlorocyclohexane $(\mathrm{HCH})$ was detected in each of the species collected from below the confluence of the two rivers, and in A. plicata collected above it on both the Mississippi and Illinois rivers, at a maximum concentration of $103.5 \mathrm{ng} / \mathrm{g} \mathrm{ww}$. Aldrin, $\delta-\mathrm{HCH}$ and dichlorodiphenyltrichloroethane (DDT) were detected in few of the specimens collected. The findings of this preliminary investigation suggest that unionid mussels from near the confluence of the Mississippi and Illinois rivers may be at risk of negative health effects of elevated exposure to certain environmental contaminants. Studies examining the health and productivity of unionid mussels from this area appear warranted.

\section{INTRODUCTION}

Freshwater mussel populations in the United States and Canada have declined dramatically over the past few decades. Two hundred thirteen of 297 known species are considered endangered, threatened, or of special concern (Williams et al. 1993, Cummings and Mayer 1992). Mussels are sensitive to environmental perturbations and are often among the first organisms to become extirpated when an aquatic system is degraded. A variety of factors, including over-harvest, siltation, and pollution from coal-mining and other activities, have been linked to their decline (Ahlstedt and Tuberville 1997, Cummings and Mayer 1992, Bogan 1993, Lydeard et al. 2004). In the state of Illinois, where 79 species in the families Margaritiferidae and Unionidae (order Unionoida) may have historically occurred, 15 species have been extirpated, 19 are listed as state endangered, and 7 are considered threatened (Cummings and Mayer 1992).

Bivalve mollusks have been used widely as indicators of environmental stress because they are sedentary and accumulate contaminants but are not efficient in metabolizing chemicals compared to some other organisms (ASTM 2001). While filter feeding, they ingest contaminants that are in solution and sorbed to fine particulate organic matter, and they are exposed to sediment-bound contaminants through pedal feeding (Moore 1971, Cope et al. 2008). Bivalves are keystone species in some aquatic environments, often constituting a large portion of the biomass, and can influence numerous ecosystem functions (Vaughn and Hakenkamp 2001). In addition, they usually provide sufficient tissue for chemical analysis and exhibit measurable sublethal effects such as reduced growth, tissue condition, glycogen levels, shell length, DNA strand breakage, cellulolytic activ- 
ity, inhibited ciliary movement on the gills, and inhibited valve movement (ASTM 2001, Allen et al. 1996, Belanger et al. 1986, 1990, Black 1997, Doherty 1990, Farris et al. 1989, Naimo et al. 1998, Newton et al. 2001, Smith and Beauchamp 2000). Furthermore, immature stages are among the most sensitive of animals in acute laboratory bioassays (Cherry et al. 2002, Jacobson et al. 1993, 1997).

The Mississippi River (MSR) basin covers a large portion of the central continental United States, which includes many cities and towns, industrial and mining areas, and a great expanse of land devoted to agriculture. As a result, the larger rivers composing this watershed carry considerable contaminant loads. Fish collected in the watershed often have elevated concentrations of bioaccumulative contaminants and at many sites are in poor health (Schmitt et al. 2002). One of the largest lead mining areas in the world is located on the upper MSR, and $\mathrm{Cd}$, chromium $(\mathrm{Cr}), \mathrm{Cu}, \mathrm{Pb}$, and $\mathrm{Hg}$ are used extensively by industries along the river (Garbarino et al. 1995). The heavy use of fertilizers can result in the introduction of large amounts of metals onto the landscape, part of which may be carried into the river by run-off. Additionally, sewage treatment plant effluents may introduce large quantities of metals such as $\mathrm{Cd}$, $\mathrm{Hg}$, and $\mathrm{Pb}$ into riverine systems. Consequently, heavy metal concentrations in suspended or bed sediments have often been elevated and have exceeded pollution criteria (Garbarino et al. 1995). The Illinois Department of Public Health currently has fish consumption advisories in effect for the MSR bordering Illinois due to elevated levels of PCBs and MeHg. Schmitt et al. (2002) reported that fish in the upper MSR subbasin commonly contained elevated concentrations of chlordane, dieldrin, PCBs, $\mathrm{As}, \mathrm{Pb}$, and $\mathrm{Zn}$.

Many towns and cities, along with defunct Zn smelters and PCB manufacturing plants, oil refineries, and other heavy industry are located in the Illinois River (ILR) drainage. Fish consumption advisories are in effect for portions of the river due to high concentrations of PCBs and MeHg. Groschen et al. (2000) reported that chlordane, dichlorodiphenyldichloroethane (DDD), dichlorodiphenyldichloroethylene (DDE), dieldrin, total PCB, 4 polycyclic aromatic hydrocarbons (PAHs), As, $\mathrm{Cd}, \mathrm{Cr}, \mathrm{Cu}, \mathrm{Pb}, \mathrm{Hg}$, Se, and $\mathrm{Zn}$ were elevated in ILR bed sediments to concentrations at or above national benchmarks for protection of benthic life. Cadmium and $\mathrm{Pb}$ concentrations in sediments were at, or in some instances above, the national average (Groschen et al. 2000). Cadmium was highly elevated in fish tissue samples from these areas, in most cases exceeding concentrations in sediments and the national average. Chlordane, dieldrin, PCBs, as well as $\mathrm{As}, \mathrm{Pb}$, and $\mathrm{Zn}$ were elevated in fish tissues collected in the lower reaches of the river (Schmitt et al. 2002). Levengood (2003) found high concentrations of $\mathrm{Cd}$ in kidneys of wood ducks collected along the ILR, and suggested that breeding ducks inhabiting this system may be chronically exposed to $\mathrm{Cd}$.

Several surveys of the mussel populations of the ILR and MSR have documented declines of sensitive species and episodic die-offs of localized populations (Blodgett and Sparks 1987). The mussel bed we sampled downstream of the confluence is considered a valuable resource due to the density and species richness of unionids (Miller et al. 1997) and is one of the few remaining beds on the upper MSR where Megalonaias nervosa, a commercially harvested species, is abundant (Ecological Specialists, Inc. 1999). A 1999 survey of Pool 26 found over 1,000 mussels representing 22 extant species, including 15 species with individuals $<3$ years of age (Ecological Specialists, Inc. 1999).

Whereas PCBs and $\mathrm{Hg}$ and other metals are known to be especially prevalent in sediments, water, and biota throughout much of the upper MSR sub-basin, no information exists on contaminants in the MSR and ILR confluence area (confluence) (but see www.umesc.usgs.gov for information on contaminants in the upper MSR), an area that may experience a mixing of contaminants from each of the rivers, as well as settling of water- and sediment-borne contaminants in slack-water off the main channel following normal high flow and flood events. This study represented a preliminary investigation of contaminant burdens in several tolerant, regionally abundant mussel species from near the confluence of the Illinois and Mississippi rivers. The overall objective of the study was to determine if concentrations of selected contaminants were elevated in mussels from the confluence, and, if so, whether concentrations might be high enough to present potential risks to mussel health and survival. This information is required to determine whether the presence 
of environmental contaminants is limiting mussel populations in this area and whether this would be expected to influence the restoration of mussel beds.

\section{METHODS}

\section{Mussels}

Five regionally abundant mussel species, Amblema plicata, Megalonaias nervosa, Quadrula quadrula, Obliquaria reflexa, and Obovaria olivaria were hand-collected from three mussel beds near the confluence of the Mississippi and Illinois rivers (Fig.1) in the autumn of 2003; a total of 109 individuals was collected (Table 1). We selected mussels of similar size to facilitate spatial comparisons among the populations of $A$. plicata. However, mussels used in this study were generally representative of the sizes encountered during sampling. Mussels were placed in coolers on wet ice until transported to the Illinois
Natural History Survey Aquatic Ecotoxicology Laboratory, Champaign, Illinois, for processing and analyses

Mussels were rinsed with deionized water to remove attached sediment or algae prior to measurements and tissue preparation. Shell length (anterior to posterior margin) and height (dorsal to ventral margin, excluding the hinge) were measured to the nearest $0.01 \mathrm{~mm}$ using digital calipers. Mussels were opened with a stainless steel knife and wet tissue was transferred into pre-weighed, disposable, polystyrene boats using a stainless steel spatula or a Teflon $^{\mathrm{TM}}$ policeman. Whole wet tissue weights were recorded to the nearest $0.0001 \mathrm{~g}$ before homogenization in a blender. Two species, $Q$. quadrula and $O$. reflexa, required composite samples of three and four mussels, respectively, to provide sufficient tissue for processing. Five grams of the homogenate were transferred to scintillation vials and stored at $-20{ }^{\circ} \mathrm{C}$ prior to

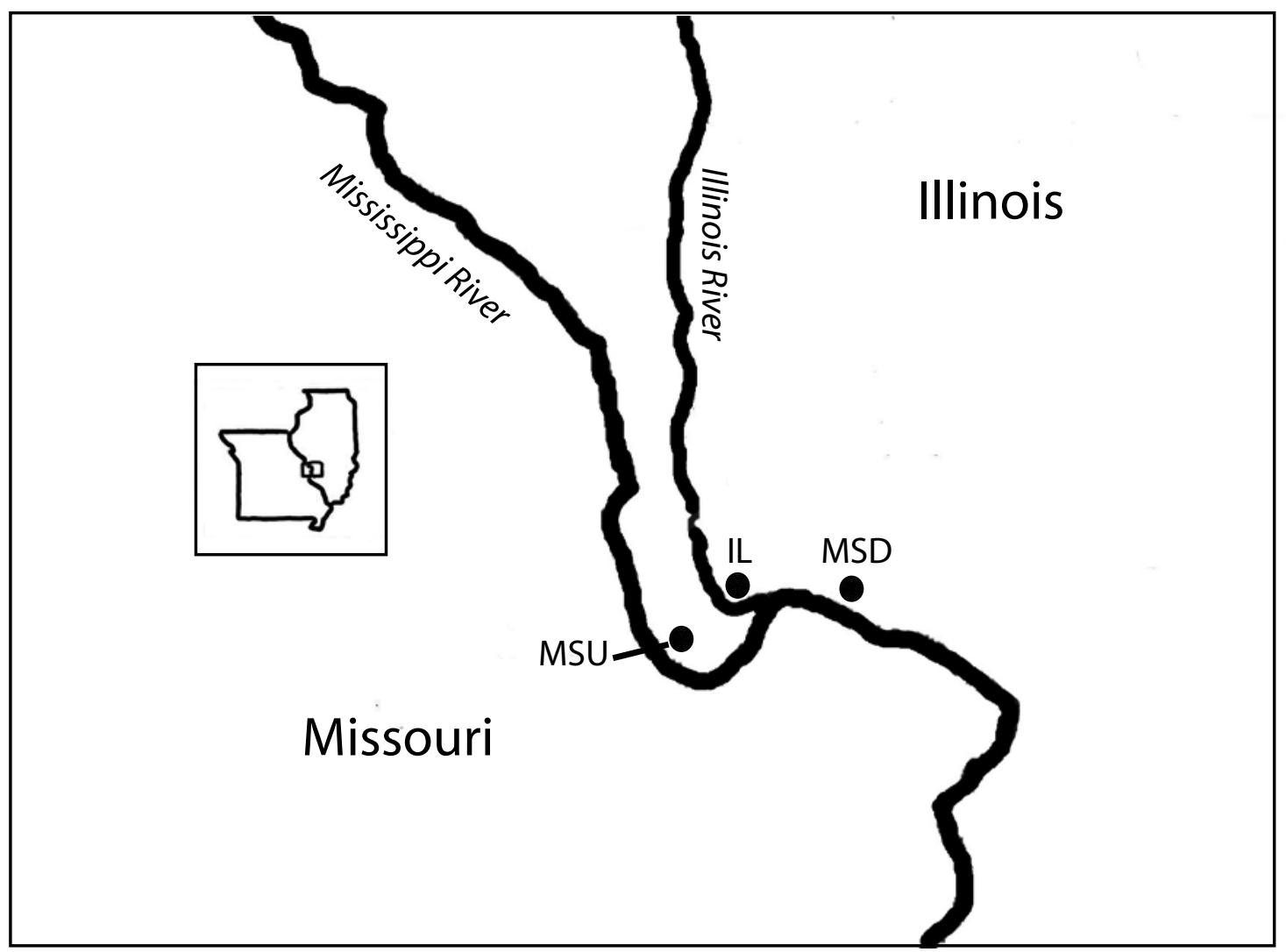

Figure 1. Map showing Mississippi and Illinois rivers confluence area on the border between Illinois and Missouri. Dots indicate sampling sites: Mississippi River upstream of its confluence with the Illinois River (MSU), Illinois River at Swan Lake (IL), and Mississippi River downstream of the confluence (MSD). 
transfer to the Cooperative Wildlife Research Laboratory at Southern Illinois University for organic contaminant analysis. Following the removal of homogenized tissue for organochlorine, $\mathrm{Hg}$, and $\mathrm{MeHg}$ analysis, measured volumes of deionized water were added to optimize homogenization for metals analysis. The weight of this addition was accounted for in calculations of a wet:dry tissue ratio. All homogenized tissue was rinsed with deionized water into preweighed $250-\mathrm{ml}$ glass beakers and oven dried at $80{ }^{\circ} \mathrm{C}$ to a constant weight. Shells were also dried to a constant weight at $80{ }^{\circ} \mathrm{C}$. Dry weights were recorded and dry homogenates were immediately transferred to plastic bags and stored at $-20^{\circ} \mathrm{C}$. Tissues for $\mathrm{Hg}$ and $\mathrm{MeHg}$ analysis were dried under vacuum at room temperature for four to five hours, pulverized with mortar and pestle, and refrigerated at $4{ }^{\circ} \mathrm{C}$ until digestion. A Tissue Condition Index (TCI) was calculated for each mussel (whole dry tissue weight / dry shell weight).

Starrett's (1971) and Whitney et al.'s (1997) studies of mussels on the Alton Reach of the Illinois River yielded aging criteria based on length or height for A. plicata, M. nervosa, Q. quadru$l a$, and $O$. reflexa. We used equations generated in both studies to determine ages for A. plicata, $M$. nervosa, $Q$. quadrula, and $O$. reflexa. Both length equations produced similar (i.e., not significantly different, $p>0.05$ ) ages for each species. No aging information was available for O. olivaria in Pool 26, thus, ages for this species were estimated by averaging ring counts made by two observers.

Tissues dried at $80{ }^{\circ} \mathrm{C}$ were prepared for elemental analysis (see below for $\mathrm{Hg}$ and $\mathrm{Se}$ determination methods) following USEPA Sample Preparation Procedure for Spectrochemical Determination of Total Recoverable Elements in Biological Tissues (USEPA 1991). Approximately $0.5 \mathrm{~g}$ of dry tissue was weighed into acidwashed 125-ml Erlenmeyer flasks. Digests were conducted using Fisher trace metal grade $\mathrm{HNO}_{3}$, $\mathrm{HCl}$, and $\mathrm{H}_{2} \mathrm{O}_{2}(30 \%)$, and were transferred into $100-\mathrm{ml}$ volumetric flasks, diluted to $100 \mathrm{ml}$ with deionized water, and homogenized. One blank was prepared for every six to nine tissue digests. Prepared samples were stored in 500-ml Nalgene ${ }^{\mathrm{TM}}$ containers at $4{ }^{\circ} \mathrm{C}$ prior to analysis for metals at the Illinois State Water Survey (ISWS) using inductively coupled argon plasma optical emission spectroscopy with a Thermo Elemental Model 61E vacuum spectrometer. Analyses were performed using USEPA Method 200.7 (USEPA 1991). The majority ( $>70 \%)$ of the calibration blanks adhered to the applicable control limits of less than the method detection limit (MDL). In other instances, the amount observed was less than or equal to five times the MDL. Initial calibration verifications met control limits (+/- 15\%) for analyses of each element and continuing calibration verifications data for each element were in the defined acceptance range of $+/-15 \%$ differences in recovery. Duplicate sample analyses for each

Table 1. Species and number of mussels collected at each site.

\begin{tabular}{llr}
\hline Site & Species & $\mathrm{n}$ \\
\hline Mississippi at Cache Hollow Rd. (MSU) & Amblema plicata & 21 \\
MRM 233.5 & Obovaria olivaria & 5 \\
& Obliquaria reflexa & 22 \\
\hline
\end{tabular}

Illinois River at mouth of Swan Lake A. plicata 
metal were within control limits, with the relative percent difference (RPD) being less than $20 \%$ when the analyte concentrations were at least 10 times the MDL.

Selenium concentrations were determined at the Illinois Sustainable Technology Center at Champaign, Illinois, by inductively coupled plasma mass spectrometry using yttrium as an internal standard. Maximum error was estimated at $+/-20 \%$, based on quality control parameters. Analytical duplicates were reproducible, ranging from $0 \%-11 \%$. Analytical and matrix spikes recovered in the range of $51 \%-87 \%$ and SRM (DOLT-2) recovered at $65 \%$. Low spike recoveries were corrected using the method of standard additions.

Tissues for total $\mathrm{Hg}$ analysis were digested using a modified procedure from EPA Method 245.5 (USEPA 1991). Pulverized tissue (0.1 to $0.3 \mathrm{~g}$ ) was mixed with $5 \mathrm{~mL}$ concentrated nitric acid (Fisher Trace Metal grade) and heated for eight hours at $65^{\circ} \mathrm{C}$. An aliquot of the acidic digest was diluted 1:4 with an ultra-low $\mathrm{Hg}$, aqueous $\mathrm{HOBr}$ solution $(10 \% \mathrm{v} / \mathrm{v})$ in a borosilicate glass vial with a fluoropolymer-lined cap (I-Chem Class 200) and then heated in an oven overnight at $60^{\circ} \mathrm{C}$. After cooling, samples were filtered using individual, acid-rinsed, $0.45-\mu \mathrm{m}$ PTFE syringe filters. Except for the heating steps, calibration standards were processed identically to samples. Diluted digests were analyzed for $\mathrm{Hg}$ using a flow-injection system with detection by cold vapor atomic fluorescence spectrometry (Shade and Hudson 2005). The detection limit of the method is $\sim 1 \mathrm{pg} \mathrm{Hg}$ absolute with a SD of $1.1 \mathrm{ng} \mathrm{g}^{-1}$ for replicate analyses. Spike recoveries were $93 \%-98 \%$ and the analysis of DOLT-2 Certified Reference Material yielded $90 \%$ of the reference value.

Methylmercury was extracted from mussels using an acid digestion followed by solvent extraction. We began by placing $0.1 \mathrm{~g}$ of mussel tissue in $5 \mathrm{~mL}$ of $4 \mathrm{M} \mathrm{HNO}_{3}$ solution and heating the solution for 1.5 hours in a laboratory oven at $70^{\circ} \mathrm{C}$. After heating, the acidic sample digests were placed in a sonicator for approximately one minute each to liquefy any remaining solid tissue. One $\mathrm{mL}$ of $30 \%$ hydroxylamine was added to each sample digest followed by shaking and then $1 \mathrm{~mL}$ of concentrated $\mathrm{HCl}$ was added, followed by shaking. Next, to separate the $\mathrm{MeHg}$ from the highly organic tissue digest, each sample digest was combined with a 5-mL aliquot of toluene and shaken for one hour. Then each acidic solution/toluene mixture was centrifuged and $4 \mathrm{~mL}$ of toluene was removed. The MeHg in the toluene was then backextracted into an aqueous thiourea solution ( $1 \%$ thiourea, $0.1 \% \mathrm{HCl}, 0.2 \%$ acetic acid) by shaking the samples for an additional 15 minutes. After centrifuging the samples again, $4 \mathrm{~mL}$ of the thiourea solution was removed and filtered. Individual acid-rinsed $0.45-\mu \mathrm{m}$ PTFE syringe filters were used to filter the final sample solution. Detection for these mussel samples was achieved using our $\mathrm{Hg}$ / TU Complex - Ion Chromatography - Flow Injection-CVAFS (Hg-Tu IC) system (Shade and Hudson 2005). A small portion (100 $\mu \mathrm{L})$ of the aqueous back-extractant was analyzed by direct injection into the HgTU/IC system. Content of $\mathrm{MeHg}$ in samples was calculated from observed peak areas for unknowns using calibration with external standards and using a correction for fractional recovery $(77 \% \pm$ $2.6 \%$ ) in samples of mussel tissue spiked with $\mathrm{MeHg}$ prior to digestion.

Tissues were analyzed for organochlorine pesticides and PCBs following the Association of Official Analytical Chemists methods for organochlorine compounds using gel permeation chromatography clean-up (USEPA 1999). Samples were homogenized with a 50/50 mix of methylene chloride and cyclohexane and dried with anhydrous sodium sulfate at a ratio of $4: 1 \mathrm{Na}_{2} \mathrm{SO}_{4}$ to tissue. The pesticide fractions were collected and dried using roto-evaporation. Samples were reconstituted with $2 \mathrm{~mL}$ of iso-octane. A Hewlett-Packard 5890 II gas chromatograph equipped with a $\mathrm{Ni}-63$ electron capture detectors and auto injectors was used to analyze the extracts. Fused silica megabore columns (DB-5 and/or DB-624) were used for the analyses. Helium was used as the carrier gas and 5\% argon-methane for make-up gas. Injection port and detector temperatures, respectively, were $250^{\circ} \mathrm{C}$ and $350^{\circ} \mathrm{C}$. Duplicates and spiked samples were analyzed with samples for quality control.

\section{Water and Sediment}

Water samples were taken at approximately mid-column and were placed in 1-L glass jars for organic contaminant analysis $(\mathrm{n}=4$ per site $)$ or $1-\mathrm{L}$ Nalgene ${ }^{\mathrm{TM}}$ bottles for metals, total carbon, hydrogen, nitrogen, and particle-size analyses $(n=1$ per site). Sediments were collected using a wide-mouth 
Nalgene $^{\text {TM }}$ container to gather the top 3 to 6 $\mathrm{cm}$ of sediment into a plastic 4-gallon tub for homogenization by stirring. Subsamples of the homogenate were transferred to 1-L glass jars for organic contaminant analysis $(n=4$ per site) and 500-ml Nalgene containers for metals analysis, $\mathrm{CHN}$ analysis, and particle-size determination ( $\mathrm{n}=1$ per site). Water and sediment samples for organic chemical analysis were stored at $-20^{\circ} \mathrm{C}$.

An aliquot was taken from the homogenized composite sample of the top few centimeters of the mussel bed. Subsamples were dried to a constant weight at $105{ }^{\circ} \mathrm{C}$ and ground to a powder with mortar and pestle. Total carbon, hydrogen, and nitrogen (CHN) analysis was conducted using a CHN/O/S Elemental Analyzer CHN440. Samples were broken into their atomic components in an oxygen atmosphere at $980{ }^{\circ} \mathrm{C}$ forming $\mathrm{CO}_{2}, \mathrm{H}_{2} \mathrm{O}$, and $\mathrm{N}_{\mathrm{x}} \mathrm{O}_{\mathrm{y}}$. These gases were carried to a detector by a helium gas stream. Samples were analyzed in duplicate. Recorded values were compared to a standard (Acetanilide, OAS), and calculations were made based on sample weight.

Particle-size analyses were conducted by using a pipette extraction procedure described in Indorante et al. (1990). Percent carbon was unknown at the time of analysis; therefore, samples were not treated with $30 \% \mathrm{H}_{2} \mathrm{O}_{2}$ to remove organic matter (a procedure that is typically performed on samples with greater than $1 \%$ organic $\mathrm{C}$ ). The resulting calculations for our ILR and MSD sediment composites theoretically could have a 5 to $10 \%$ lower clay-size content and a 5 to $10 \%$ higher silt content due to this omission.

Metals analyses for a composite sediment sample from each site were conducted by the Illinois Sustainable Technology Center. Prior to digestion, disaggregated sediment samples were shaken to homogenize them. Representative portions of each sediment sample were used in a nitric and hydrofluoric acid microwave digestion procedure, equivalent to US EPA Method 3052 (USEPA 1999), to dissolve sample matrices into solution for total metals analysis. Results were obtained by inductively coupled plasma mass spectrometry using scandium, yttrium, and thorium as internal standards. Quality control parameters pose an uncertainty of no more than $+/-20 \%$ for all metals except $\mathrm{Al}$. Although $\mathrm{Fe}, \mathrm{Pb}$, and $\mathrm{Zn}$ were observed in digested blanks, the concen- trations were extremely low compared with sample concentration levels. Relative percent differences of digested duplicates ranged from 1 to $14 \%$. Recoveries of analytical spikes, matrix spikes, and a Standard Reference Material (SRM \#2710, NIST Montana Soil) ranged from 76 to $126 \%$. Aluminum was high in digested blanks and only recovered at $23 \%$ from the SRM. Samples and SRM Al concentrations were $>1 \%$, therefore values reported herein are minimums.

Sediment was homogenized with sodium sulfate and Soxhlet extracted with 50 $\mathrm{mL}$ hexane for 30 minutes. The extract was transferred to a round-bottom flask and reduced using rotary evaporation and solvent exchanged to hexane. Clean-up followed using a Florisil column to separate PCB fractions from organochlorine pesticides. Each fraction was reduced to $1 \mathrm{~mL}$ final volume for analysis by GC/ECD. Water samples were liquid-liquid extracted three times by adding $60 \mathrm{~mL}$ of methylene chloride (MC) to $1 \mathrm{~L}$ of water sample in a separatory funnel. The MC layer was decanted and new MC added for each of the three extractions. The extract was then reduced using rotary evaporation, solvent-exchanged to hexane, and clean-up with Florisil for fraction separation as described for sediment. The same instrumentation and analytical methods were used as described for tissue extracts.

\section{Statistical Comparisons}

Elemental tissue concentrations and morphological parameters of A. plicata were compared spatially using one-way ANOVA $(\alpha=$ 0.05 ) followed by Bonferroni multiple comparisons. The entire data set $(n=30)$ was analyzed for normality (Shapiro-Wilks); non-normal data were $\log _{10}$ transformed and reanalyzed. If data were still non-normal, we used a nonparametric test (Kruskal-Wallis, $\alpha=0.05$ ). Elemental tissue concentrations and morphological parameters were compared among species collected from the MSR upstream (MSU) and downstream (MSD) of its confluence with the ILR. Since interspecific elemental concentration comparisons were made using fewer samples ( $n=5$ per species), the same nonparametric test was used. In both spatial and interspecific comparisons, some elements were below the Method Detection Limit (MDL) in several mussel samples. For instances in which at least $40 \%$ of the data being analyzed were below 
the MDL, means for each species are reported on the number of samples with concentrations above the MDL and are indicated as such.

Statistical comparisons were not performed on these elements; however, descriptive statistics are provided. For instances in which $<40 \%$ of the data were below the MDL, a value of onehalf the MDL was used. Organic contaminants were detected in too few mussel tissue samples, sediment samples, and water samples to allow statistical comparisons.

\section{RESULTS}

Total carbon concentrations in bed sediment ranged from $1.0 \%$ at MSU to $1.8 \%$ at MSD (Table 2). Proportions of clay, silt, and sand were also variable among sites. Water quality characteristics including $\mathrm{pH}$, conductivity, alkalinity, and hardness at the two MSR sites were quite similar, whereas ILR had higher values for conductivity, alkalinity, and hardness (Table 3 ). With the exception of $\mathrm{Cr}$ in sediments at ILR and MSD, concentrations of elements in both media were relatively low (Table 4). Amblema pictata specimens were physically similar across sites in terms of mean length (anterior to posterior margin), mean height (dorsal to ventral margin), dry shell weight, and TCI (Table 5). Amblema pictata from the ILR had significantly higher wet tissue weights than did specimens from both of the MSR sites $(\mathrm{p}<0.02)$. However, because other morphometrics and, therefore, calculated mean ages, were not significantly different, mussels were considered to be of the same cohort and useful for spatial comparisons of contaminant loads. Ambleme pictata, $M$. nervosa, and $Q$. quadrula collected at MSD varied by size and age $(\mathrm{p}<0.001$, Table 5).

Table 2. Total organic carbon, hydrogen, and nitrogen content and texture characteristics of composite sediment samples from the Mississippi River upstream (MSU) and downstream (MSD) of the river confluence, and the Illinois River by Swan Lake (ILR).

\begin{tabular}{l|c|c|c}
\hline $\begin{array}{l}\text { Sediment } \\
\text { characteristic }\end{array}$ & MSU & ILR & MSD \\
\hline$\% \mathrm{C}$ & 0.95 & 1.645 & 1.79 \\
$\% \mathrm{H}$ & 0.15 & 0.405 & 0.19 \\
$\% \mathrm{~N}$ & 0.045 & 0.135 & 0.075 \\
& & & \\
$\%$ Clay & 6.62 & 22.77 & 8.74 \\
$\%$ Silt & 16.66 & 74.47 & 42.23 \\
\% Sand & 76.72 & 2.76 & 48.25 \\
Soil Type & loamy sand & silt loam & loam \\
\hline
\end{tabular}

Table 3. Water quality characteristics of grab samples from the Mississippi River upstream (MSU) and downstream (MSD) of the river confluence and the Illinois River by Swan Lake (ILR).

\begin{tabular}{l|c|c|c|c}
\hline Site & $\mathrm{pH}$ & $\begin{array}{c}\text { Conductivity } \mu \mathrm{S} / \\
\mathrm{cm}\end{array}$ & $\begin{array}{c}\text { Alkalinity } \\
\mathrm{mg} / \mathrm{L} \mathrm{CaCO}_{3}\end{array}$ & $\begin{array}{c}\text { Hardness } \\
\mathrm{mg} / \mathrm{L} \mathrm{CaCO}_{3}\end{array}$ \\
\hline MSU & 7.8 & 404 & 160 & 180 \\
ILR & 7.7 & 748 & 200 & 272 \\
MSD & 8.1 & 441 & 162 & 190 \\
\hline
\end{tabular}


Concentrations of $\mathrm{Zn}$ did not vary with age in A. plicata, M. nervosa, Q. quadrula or O. reflexa. However, we did observe a significant relationship between tissue $\mathrm{Cd}$ and age in A. plicata from both $\operatorname{MSD}\left(\mathrm{R}^{2}=0.71, \mathrm{P}=0.002\right)$ and ILR $\left(\mathrm{R}^{2}=0.37\right.$, $\mathrm{P}=0.08)$, though not MSU $\left(\mathrm{R}^{2}=0.09, \mathrm{P}=0.41\right)$; in both significant cases, this relationship was negative.

The mean concentrations of $\mathrm{Cu}(\mathrm{P}=0.03), \mathrm{Se}$ $(\mathrm{P}<0.001)$, and $\mathrm{Zn}(\mathrm{p}<0.001)$ were highest, and $\mathrm{Pb}$ ( $\mathrm{P}=0.001$ ), and $\mathrm{Cd}$ (nominally) were lowest in $A$. plicata from MSD (Table 6). Mean concentrations of $\mathrm{Cu}, \mathrm{Pb}$, and $\mathrm{Se}$ were intermediate and $\mathrm{Zn}$ was lowest in mussels from ILR. Total Hg concentrations were low and did not differ among sites for A. plicata; however, a significant difference was observed for $\mathrm{MeHg}(\mathrm{P}=0.01)$, with the highest mean concentration observed at MSU (Table 6).

Amblema plicata tissue from MSD contained significantly higher concentrations of $\mathrm{Zn}(\mathrm{P}=0.01)$ compared to $M$. nervosa, which in turn had higher concentrations of both $\mathrm{Pb}(\mathrm{P}=0.02)$ and $\mathrm{Zn}$ than Q. quadrula (Table 7). Quadrula quadrula was characterized by higher total $\mathrm{Hg}$ concentrations $(\mathrm{P}=$ 0.03 ), as compared to A. plicata at MSD (Table 7).

Table 4. Priority element concentrations in composite sediment $(\mathrm{mg} / \mathrm{kg} \mathrm{dw}$ ) and water $(\mathrm{mg} / \mathrm{L})$ samples from the Mississippi River upstream (MSU) and downstream (MSD) of the confluence and the Illinois River by Swan Lake (ILR).

\begin{tabular}{|c|c|c|c|c|c|c|}
\hline \multirow[b]{2}{*}{ Element } & \multicolumn{2}{|c|}{ MSU } & \multicolumn{2}{|c|}{ ILR } & \multicolumn{2}{|c|}{ MSD } \\
\hline & sediment & water & sediment & water & sediment & water \\
\hline$\overline{\mathrm{Ag}}$ & 0.19 & - & 0.22 & - & 0.15 & - \\
\hline As & - & $<0.037$ & - & $<0.037$ & - & $<0.037$ \\
\hline $\mathrm{Be}$ & - & $<0.002$ & - & $<0.002$ & - & $<0.002$ \\
\hline $\mathrm{Cd}$ & 0.16 & $<0.003$ & 0.40 & $<0.003$ & 0.25 & $<0.003$ \\
\hline $\mathrm{Cr}$ & 27 & $<0.004$ & 53 & 0.01 & 43 & $<0.004$ \\
\hline $\mathrm{Cu}$ & 8 & $<0.003$ & 21 & $<0.003$ & 12 & $<0.003$ \\
\hline $\mathrm{Ni}$ & - & 0.01 & - & 0.02 & - & 0.01 \\
\hline $\mathrm{Pb}$ & 15 & $<0.028$ & 24 & $<0.028$ & 19 & $<0.028$ \\
\hline $\mathrm{Sb}$ & - & $<0.021$ & - & $<0.021$ & - & $<0.021$ \\
\hline $\mathrm{Se}$ & $<0.02$ & $<0.034$ & $<0.02$ & $<0.034$ & $<0.02$ & $<0.034$ \\
\hline $\mathrm{Zn}$ & 33 & 0.01 & 83 & 0.00 & 48 & 0.00 \\
\hline
\end{tabular}

- indicates not analyzed

Table 5. Mean \pm sd length, height, weight, moisture content, $\mathrm{TCI}^{2}$, and calculated age (per Starrett 1971 and Whitney et al. 1997) of mussels collected during 2003 from three sites near the confluence of the Mississippi and Illinois rivers. Collection sites were Mississippi River upstream (MSU) and downstream (MSD) of the confluence and the Illinois River by Swan Lake (ILR). Numbers in parentheses are sample sizes.

\begin{tabular}{|c|c|c|c|c|c|}
\hline & \multirow{2}{*}{$\begin{array}{c}\text { MSU } \\
\begin{array}{c}\text { Amblema } \\
\text { plicata (10) }\end{array}\end{array}$} & \multirow{2}{*}{$\frac{\text { ILR }}{\text { A.plicata }(10)}$} & \multicolumn{3}{|c|}{ MSD } \\
\hline & & & A.plicata $(10)$ & $\begin{array}{l}\text { Megalonaias } \\
\text { nervosa (5) }\end{array}$ & $\begin{array}{c}\text { Quadrula } \\
\text { quadrula }(14)^{3}\end{array}$ \\
\hline Length (mm) & $99.5 \pm 5.9 \mathrm{~A}$ & $104 \pm 4 \mathrm{~A}$ & $100 \pm 5 \mathrm{~A}$ & $143 \pm 17$ & $60.8 \pm 5.5$ \\
\hline Height $(\mathrm{mm})^{1}$ & $75.7 \pm 3.5 \mathrm{~A}$ & $77.5 \pm 2.7 \mathrm{~A}$ & $76.3 \pm 4.5 \mathrm{~A}$ & $103.4 \pm 7.9$ & $54 \pm 4.2$ \\
\hline Wet tissue weight (g) & $38.17 \pm 5.6 \mathrm{~B}$ & $47.4 \pm 10.2 \mathrm{~A}$ & $38.7 \pm 5.9 \mathrm{~A}$ & $91.3 \pm 24.9$ & $34.8 \pm 3.6$ \\
\hline$\%$ water & $0.82 \pm 0.01$ & $0.83 \pm 0.02$ & $0.82 \pm 0.01$ & $0.84 \pm 0.02$ & $0.82 \pm 0.01$ \\
\hline Dry shell weight (g) & $169 \pm 34 \mathrm{~A}$ & $196 \pm 29 \mathrm{~A}$ & $177 \pm 33 \mathrm{~A}$ & $335 \pm 95$ & $154 \pm 19$ \\
\hline $\mathrm{TCI}^{2}$ & $4.2 \pm 0.6 \mathrm{~A}$ & $4.2 \pm 0.8 \mathrm{~A}$ & $3.9 \pm 0.4 \mathrm{~A}$ & $4.5 \pm 1$ & $4.2 \pm 0.3$ \\
\hline Age (yr) & $16.5 \pm 2.5 \mathrm{~A}$ & $18.2 \pm 2.0 \mathrm{~A}$ & $16.8 \pm 2.9 \mathrm{~A}, \mathrm{a}$ & $12.9 \pm 3.9 b$ & $9.6 \pm 1.0 c$ \\
\hline
\end{tabular}

Different capital letters indicate means for A. plicata are significantly different among sites $(\mathrm{p}<0.05)$. Different lower case letters indicate significantly different means among species at a site $(\mathrm{p}<0.05)$.

${ }^{1}$ Height does not include hinge.

${ }^{2}$ Tissue Condition Index = dry tissue weight / dry shell weight

${ }^{3} Q$. quadrula TCI, wet tissue weight, and \% water measurements are based on five composites of three mussels each (one composite has two mussels). 
Table 6. Mean \pm sd concentrations* ( $\mathrm{mg} / \mathrm{kg}$ dry weight) of EPA priority elements and methylmercury in tissues of Amblema plicata collected from near the confluence of the Mississippi and Illinois rivers. Locations are Mississippi River upstream (MSU) and downstream (MSD) of the confluence and the Illinois River by Swan Lake (ILR). MDL = method detection limit $(\mathrm{mg} / \mathrm{kg} \mathrm{d})$

\begin{tabular}{lcccc}
\hline Element & MDL & $\begin{array}{c}\text { MSU } \\
(\mathrm{n}=10)\end{array}$ & $\begin{array}{c}\text { ILR } \\
(\mathrm{n}=10)\end{array}$ & $\begin{array}{c}\text { MSD } \\
(\mathrm{n}=10)\end{array}$ \\
\hline $\mathrm{As}$ & 7.08 & $10.4(1)$ & $<\mathrm{MDL}$ & $<\mathrm{MDL}$ \\
$\mathrm{Cd}$ & 0.57 & $1.25(4) \pm 0.45$ & $1.27(6) \pm 0.30$ & $1.06(6) \pm 0.27$ \\
$\mathrm{Cr}$ & 0.77 & $4.3 \pm 1.6 \mathrm{~A}$ & $3.1 \pm 0.7 \mathrm{~A}$ & $3.1 \pm 0.7 \mathrm{~A}$ \\
$\mathrm{Cu}$ & 0.57 & $9.8 \pm 2.4 \mathrm{~A}$ & $11.7 \pm 4.1 \mathrm{AB}$ & $14.8 \pm 5.1 \mathrm{~B}$ \\
$\mathrm{Hg}$ & - & $0.0350 \pm 0.0062$ & $0.0311 \pm 0.0017$ & $0.0352 \pm 0.0035$ \\
$\mathrm{MeHg}$ & - & $0.0213 \pm 0.0018$ & $0.0147 \pm 0.0016$ & $0.0191 \pm 0.0022$ \\
$\mathrm{Ni}$ & 1.34 & $6.4 \pm 7.4 \mathrm{~A}$ & $3.84 \pm 1.9 \mathrm{~A}$ & $13.8 \pm 30.6 \mathrm{~A}$ \\
$\mathrm{~Pb}$ & 5.36 & $9.4 \pm 1.8$ & $8.7 \pm 2.8$ & $3.5 \pm 2.4$ \\
$\mathrm{Sb}$ & 4.02 & $11.1(8) \pm 3.4$ & $<\mathrm{MDL}$ & $7.7(3) \pm 2.8$ \\
$\mathrm{Se}$ & 6.51 & $2.03 \pm 0.35 \mathrm{~A}$ & $2.59 \pm 0.34 \mathrm{~B}$ & $2.91 \pm 0.26 \mathrm{~B}$ \\
$\mathrm{Zn}$ & 0.38 & $219 \pm 45 \mathrm{~A}$ & $165 \pm 27 \mathrm{~B}$ & $293 \pm 77 \mathrm{C}$ \\
\hline
\end{tabular}

- indicates MDL not reported

*like letters indicate means not different by Bonferroni method

${ }^{*} \mathrm{~Pb}$ and $\mathrm{Hg}$ data were compared using Kruskal Wallis (nonparametric test) testing .

For As, $\mathrm{Cd}$, and $\mathrm{Sb}, 40 \%$ or more of the analyte concentrations in the data set were at or below the MDL. In those cases, numbers in parentheses indicate that means and standard deviations for the analyte were calculated only from those sample concentrations that are above the MDL. No statistical comparisons were made on these analytes.

Table 7. Mean \pm sd concentrations* ( $\mathrm{mg} / \mathrm{kg}$ dry weight) of EPA priority elements and methylmercury in three mussel species collected from below the confluence of the Mississippi and Illinois rivers. MDL $=$ method detection limit (mg/kg dw).

\begin{tabular}{lcccc}
\hline Element & MDL & $\begin{array}{c}\text { Amblema } \\
\text { plicata } \\
(\mathrm{n}=10)\end{array}$ & $\begin{array}{c}\text { Megalonaias } \\
\text { nervosa } \\
(\mathrm{n}=5)\end{array}$ & $\begin{array}{c}\text { Quadrula } \\
\text { quadrula } \\
(\mathrm{n}=5)\end{array}$ \\
\hline $\mathrm{As}$ & 7.08 & $<\mathrm{MDL}$ & $<\mathrm{MDL}$ & $<\mathrm{MDL}$ \\
$\mathrm{Cd}$ & 0.57 & $1.06(6) \pm 0.27$ & $0.70(1)$ & $1.05(1)$ \\
$\mathrm{Cr}$ & 0.77 & $3.1 \pm 0.7$ & $3.1 \pm 0.6$ & $2.4 \pm 0.6$ \\
$\mathrm{Cu}$ & 0.57 & $14.8 \pm 5.1$ & $16.6 \pm 4.2$ & $15.2 \pm 1.2$ \\
$\mathrm{Hg}$ & - & $0.0352 \pm 0.0035$ & $\mathrm{NM}$ & $0.0454 \pm 0.0059$ \\
$\mathrm{MeHg}$ & - & $0.0191 \pm 0.0022$ & $\mathrm{NM}$ & $0.0276 \pm 0.0056$ \\
$\mathrm{Ni}$ & 1.34 & $13.8 \pm 30.6$ & $9.3 \pm 9.2$ & $23.9 \pm 29.0$ \\
$\mathrm{~Pb}$ & 5.36 & $10.2(1)$ & $11.1(4) \pm 3.3$ & $6.28(3) \pm 1.2$ \\
$\mathrm{Sb}$ & 4.02 & $7.7(3) \pm 2.8$ & $6.7(2) \pm 1.5$ & $4.5(1)$ \\
$\mathrm{Se}$ & 6.51 & $2.91 \pm 0.26$ & $\mathrm{NM}$ & $\mathrm{NM}$ \\
$\mathrm{Zn}$ & 0.38 & $293 \pm 77$ & $241 \pm 32$ & $188 \pm 23$ \\
\hline
\end{tabular}

- indicates MDL not reported

$\mathrm{NM}=$ not measured

*like letters indicated means not different by Bonferroni method

** $\mathrm{Pb}$ and $\mathrm{Hg}$ data were compared using Kruskal Wallis (nonparametric test) testing .

In some cases $(\mathrm{Cd}, \mathrm{Pb}, \mathrm{Sb}), 40 \%$ or more of the analyte concentrations in the data set were at or below the MDL. In those cases, numbers in parentheses indicate that means and standard deviations for the analyte were calculated only from those sample concentrations that are above the MDL. No statistical comparisons were made with these values. 
We observed significant differences in concentrations of $\mathrm{Ni}(\mathrm{P}=0.02)$ and $\mathrm{Zn}(\mathrm{P}=0.002)$ among $A$. plicata, $M$. nervosa, and $Q$. quadrula from MSU (Table 8). Concentrations of Ni were highest in $O$. reflexa, whereas $\mathrm{Zn}$ concentrations were by far greatest in A. plicata. There were no significant differences in total $\mathrm{Hg}$ among the three species collected at MSU; however, the mean concentration of $\mathrm{MeHg}$ was highest in O. olivaria $(\mathrm{P}=0.02$; Table 8$)$.

A number of PCB congeners were detected in A. plicata tissues; 17 of 20 detections were at MSD (Table 9). There were no PCBs observed in M. nervosa or Q. quadrula. Few organochlorine pesticides were detected. $\beta$-hexachlorocyclohexane was detected in all three species collected at MSD and in A. plicata at MSU and ILR, at a maximum concentration of $103.5 \mathrm{ppb} w w$. Aldrin and $\delta-\mathrm{HCH}$ were each detected once, both in an A. plicata specimen from MSD. Dichlordiphenyltrichloroethane was detected in one $Q$. quadrula mussel (8.9 ppb ww) at MSD and in one water sample (14 ppb) at ILR.

\section{DISCUSSION}

Numerous biotic and abiotic factors contribute to the variability of contaminant concentrations in freshwater mussel populations. Bioavailability of contaminants is often predicted based on media characteristics such as water hardness, $\mathrm{pH}$, dissolved organic carbon concentration, and sediment organic matter or sulfur content (e.g., Grabowski et al. 2001, and see Paquin et al. 2003). Complex models like the Biotic Ligand Model (BLM) have been developed to predict metal uptake and therefore, toxicity, based on chemical and physical properties of a system (Paquin et al. 2002). For example, anions such as chlorides, hydroxides, carbonates, nitrates, and dissolved organic matter can bind metal ions and render them unavailable for biological uptake. Cations like calcium and sodium can compete at the gill-binding site, thus reducing the number of toxic metal ions that can bind to the gill (see Paquin et al. 2002). In anaerobic sediments, relative levels of acid volatile sulfide (AVS) and simultane-

Table 8. Mean \pm sd concentrations ( $\mathrm{mg} / \mathrm{kg}$ dry weight) of EPA priority elements and methylmercury in tissues of three mussel species collected from the Mississippi River upstream from its confluence with the Illinois River. $\mathrm{MDL}=$ method detection limit $(\mathrm{mg} / \mathrm{kg} \mathrm{dw})$.

\begin{tabular}{ccccc}
\hline Element & MDL & $\begin{array}{c}\text { Amblema } \\
\text { Plicata } \\
(\mathrm{n}=10)\end{array}$ & $\begin{array}{c}\text { Obliquaria } \\
\text { reflexa } \\
(\mathrm{n}=5)\end{array}$ & $\begin{array}{c}\text { Obovaria } \\
\text { olivaria } \\
(\mathrm{n}=5)\end{array}$ \\
\hline $\mathrm{As}$ & 7.08 & $10.43(1)$ & $<\mathrm{MDL}$ & $<\mathrm{MDL}$ \\
$\mathrm{Cd}$ & 0.57 & $1.25(4) \pm 0.45$ & $<\mathrm{MDL}$ & $0.71(2) \pm 0.02$ \\
$\mathrm{Cr}$ & 0.77 & $4.3 \pm 1.6$ & $4.1 \pm 1.8$ & $3.1 \pm 1.6$ \\
$\mathrm{Cu}$ & 0.57 & $9.8 \pm 2.4$ & $12.2 \pm 5.9$ & $7.9 \pm 1.5$ \\
$\mathrm{Hg}$ & - & $0.0350 \pm 0.0062$ & $0.0303 \pm 0.0035$ & $0.0360 \pm 0.0029$ \\
$\mathrm{MeHg}$ & - & $0.0213 \pm 0.0018$ & $0.0199 \pm 0.0018$ & $0.0254 \pm 0.0031$ \\
$\mathrm{Ni}$ & 1.34 & $6.4 \pm 7.4$ & $30.4 \pm 40.7$ & $18.8 \pm 27.6$ \\
$\mathrm{~Pb}$ & 5.36 & $9.4 \pm 1.8$ & $7.9 \pm 4.2$ & $5.0 \pm 3.8$ \\
$\mathrm{Sb}$ & 4.02 & $11.11(8) \pm 3.4$ & $6.55(2) \pm 1.6$ & $7.49(2) \pm 1.3$ \\
$\mathrm{Se}$ & 6.51 & $2.03 \pm 0.35$ & $\mathrm{NM}$ & $\mathrm{NM}$ \\
$\mathrm{Zn}$ & 0.38 & $219 \pm 45$ & $90 \pm 18$ & $134 \pm 46$ \\
\hline
\end{tabular}

- indicates MDL not reported

$\mathrm{NM}=$ not measured

* Nonparametric tests were conducted because of small sample sizes; therefore, no pair-wise comparisons were made.

In some cases (As, $\mathrm{Cd}, \mathrm{Sb}$ ), $40 \%$ or more of the analyte concentrations in the data set were at or below the MDL. In those cases, numbers in parentheses indicate that means and standard deviations for the analyte were calculated only from those sample concentrations that are above the MDL. No statistical comparisons were made with these values. 
Table 9. Range of concentrations of organic contaminants ${ }^{\mathrm{a}}$ detected in mussels ${ }^{\mathrm{b}}(\mathrm{ng} / \mathrm{g} \mathrm{ww})$ from the Mississippi and Illinois rivers. Sites are Mississippi River upstream (MSU) and downstream (MSD) of the confluence and the Illinois River by Swan Lake (ILR). $<5$ indicates all mussels had concentrations lower than detection limits. Values in parentheses indicate the numbers of mussels with values greater than detection limits.

\begin{tabular}{|c|c|c|c|c|c|}
\hline \multirow[b]{2}{*}{ Compound } & \multicolumn{3}{|c|}{$\begin{array}{l}\text { Amblema } \\
\text { plicata }\end{array}$} & \multirow{2}{*}{$\begin{array}{c}\text { Megalonaias } \\
\frac{\text { nervosa }}{\text { MSD }}\end{array}$} & \multirow{2}{*}{$\begin{array}{r}\text { Quadrula } \\
\frac{\text { quadrula }}{\mathrm{MSD}}\end{array}$} \\
\hline & MSU & ILR & $\overline{\mathrm{MSD}}$ & & \\
\hline$\overline{\mathrm{PCB}}$ congeners & & & & & \\
\hline pcb18 & $<5-15.4(1)$ & $<5-6.5(1)$ & $<5$ & $<5$ & $<5$ \\
\hline cb28 & $<5$ & $<5-5.9(1)$ & $<5$ & $<5$ & $<5$ \\
\hline cb44 & $<5$ & $<5$ & $<5-18.5(3)$ & $<5$ & $<5$ \\
\hline cb43+49 & $<5$ & $<5$ & $<5-11.5(1)$ & $<5$ & $<5$ \\
\hline $\operatorname{cb} 48$ & $<5$ & $<5$ & $<5-23.7(4)$ & $<5$ & $<5$ \\
\hline $\operatorname{cb} 52$ & $<5$ & $<5$ & $<5-32.4(1)$ & $<5$ & $<5$ \\
\hline $\operatorname{cb} 128$ & $<5$ & $<5$ & $<5-19.9(1)$ & $<5$ & $<5$ \\
\hline $\operatorname{cb} 153$ & $<5$ & $<5$ & $<5-32.9(2)$ & $<5$ & $<5$ \\
\hline cb156+200 & $<5$ & $<5$ & $<5-21.6(1)$ & $<5$ & $<5$ \\
\hline cb167+183 & $<5$ & $<5$ & $<5-22.08(3$ & $<5$ & $<5$ \\
\hline $\operatorname{cb} 187$ & $<5$ & $<5$ & $<5-38.2(1)$ & $<5$ & $<5$ \\
\hline \multicolumn{6}{|c|}{ Organochlorine pesticides } \\
\hline$\beta-\mathrm{HCH}$ & $<5-12.6(2)$ & $<5-18.7(4)$ & $<5-103.5(1)$ & $<5-20.4(3)$ & $<5-24.9(5)$ \\
\hline$\delta-\mathrm{HCH}$ & $<5$ & $<5$ & $<5-10.5(1)$ & $<5$ & $<5-5.2(1)$ \\
\hline Aldrin & $<5$ & $<5$ & $<5-5.9(1)$ & $<5$ & $<5$ \\
\hline DDT & $<5$ & $<5$ & $<5$ & $<5$ & $<5-8.8(1)$ \\
\hline
\end{tabular}

aAnalytes measured but never found above detection limits included: PCB 8, 66, 77+110, 86, 87, 99, 101, $105,118,138,183,170,180,195,200,206$; dichlorobenzophenone, $\alpha-\mathrm{HCH}, \gamma$-HCH, heptachlor, heptachlor epoxide, $\gamma$-chlordane, $\alpha$-chlordane, endosulfan I, endosulfan II, endosulfan sulfate, dieldrin, endrin, endrin aldehyde, endrin ketone, methoxychlor, DDD, DDE.

${ }^{\mathrm{b}}$ All values for sediments were below detection limits, and all for water were below detection limits except for DDT $(<10-14(1)$.

ously extracted metals (SEM) can be used as an estimate of bioavailability (Berry et al. 1996, DiToro et al. 1990). In this study, ILR sediments had the highest priority metal concentrations; however, they had higher proportions of clay and silt than the MSR sites, as well as higher Fe and Mn concentrations. Clays and organic matter found in silts readily bind metals as do Fe and Mn. These factors may explain why A. plicata specimens from the ILR did not have the highest metal concentrations in their tissues, despite the sediments being the most contaminated. Concentrations of $\mathrm{Cu}$, $\mathrm{Se}$, and $\mathrm{Zn}$ in A. plicata were most often highest at MSD, which also had the highest \% carbon in sediments. We suggest that factors influencing the availability of contaminants to mussels in the confluence area receive further study.

The concentrations of $\mathrm{Cd}$ we observed in tissues of $A$. plicata fell within the range of those observed by Naimo et al. (1992) in this species from MSR Pools 3 (south of Minneapolis, MN) and 10 (north of Dubuque, IA), and were similar to background levels reported by Adams et al. (1981) (Fig. 2). Adams et al (1981) reported much higher concentrations of Cd in A. plicata transplanted to a contaminated portion of the Tippecanoe River in Indiana. Hinch and Stephenson (1987) also observed much higher concentrations of $\mathrm{Cd}$ in the unionid Elliptio complanata from Ontario, Canada, than we did in A plicata from Pool 26. 
Mean concentrations of $\mathrm{Zn}$ in A. plicata from Pool 26 were higher at two of the three sites (MSU and MSD) compared to those reported by Naimo et al. (1992) (Fig. 2). Zinc concentrations in A. plicata transplanted to a contaminated tributary of the Tippecanoe River in Indiana were as high as $388 \mathrm{ppm}$ dw (Adams et al. 1981). The maximum $\mathrm{Zn}$ concentration (397 ppm) observed in our study surpassed that maximum, despite the fact that our water and sediment $\mathrm{Zn}$ concentrations were much lower. However, the organisms in that study were transplanted only seven days prior to analysis, whereas A. plicata in our study were present for 16 to 18 years. Mean concentrations of $\mathrm{Zn}$ in the unionid Elliptio complanata from two lakes in Ontario, Canada, were similar to those found in our study (Hinch and Stephenson 1987).

Mean concentrations of $\mathrm{Cu}$ in mussels in our study were higher than reported by Naimo et al. (1992), for A. plicata from the MSR, though they were similar to those in the unionid $\mathrm{El}$ liptio complanata from two lakes in Ontario, Canada (Hinch and Stephenson 1987).

Total Hg concentrations we observed were an order of magnitude lower than reported by Naimo et al. (1992) in this species from the upper MSR (Fig. 3). Metcalfe-Smith et al. (1996) examined levels of elements in the tissue of unionids from a portion of the St. Lawrence River, Quebec, Canada, "heavily contaminated" with metals from steel, iron, and pigment production facilities. Tissue $\mathrm{Cr}$ concentrations in that study were substantially higher, whereas mean concentrations of $\mathrm{As}, \mathrm{Cd}, \mathrm{Cu}, \mathrm{Pb}, \mathrm{Se}$, and $\mathrm{Zn}$ were similar to or lower than those we observed.

Whereas interspecific differences often contribute the most to variability in metal burdens among mussels, age is an important factor within a species (Metcalfe-Smith et al. 1996, Naimo 1995). Hinch and Stephenson (1987) observed significant correlations between agelength and $\mathrm{Cd}$ and $\mathrm{Zn}$ concentrations in the unionid Elliptio complanata. Metcalfe-Smith et al. (1996) found that for some metals, e.g., $\mathrm{Zn}$, species was the best predictor of tissue concentrations, whereas for others, e.g., Cd, age-size was the most important factor determining variation in concentrations of those elements in unionid tissue. We found that concentrations of $\mathrm{Zn}$ did not vary by age within species. In contrast, concentrations of $\mathrm{Cd}$ were higher in tissues of younger A plicata at two of three sites. Although Metcalfe-Smith et al. (1996) observed positive relationships between $\mathrm{Cd}$ and age in two unionid species, their review of studies examining relationships between metal concentrations and size (age) in unionids revealed that, for $\mathrm{Cd}$ in mussels from "clean" sites, the relationship, if one existed, was more often negative than positive; few studies of contaminated sites addressed this issue. The reasons for the negative relationship between $\mathrm{Cd}$ and age in A plicata in our study can only be surmised. Younger bivalves may accumulate some metals at a more raid rate (Strong and Luoma 1981). Also, it is plausible that temporal changes in environmental concentrations of bioaccumulative metals such as $\mathrm{Cd}$ could be reflected in tissues of unionid mussels. A more detailed investigation of intraspecific patterns of metal uptake in mussels from the confluence area is needed to clarify observed patterns.

Studies associating physiological effects with tissue contaminant loads in freshwater mussels are few. Mean whole-tissue concentrations of $\mathrm{Cu}$ approaching $20 \mu \mathrm{g} / \mathrm{g}$ ww (118 $\mu \mathrm{g} / \mathrm{g} \mathrm{dw}$ ) were associated with mortality in Q. quadrula transplanted downstream of a $\mathrm{Cu}$ electroplating plant (Foster and Bates 1978). Population reductions were associated with increased body burdens up to $37 \mathrm{~km}$ downstream, where concentrations of $\mathrm{Cu}$ averaged $9.5 \mu \mathrm{g} / \mathrm{g}$ ww $(56 \mu \mathrm{g} / \mathrm{g} \mathrm{dw})$. Tissue concentrations in our study did not approach these levels.

Salazar et al. (1995) observed that mean $\mathrm{MeHg}$ concentrations of $43 \mu \mathrm{g} / \mathrm{kg}$ were associated with reductions in soft-body weights of Elliptio complanata transplanted to a contaminated site. $\mathrm{MeHg}$ concentrations in eight individuals in our study approached or exceeded that level, so similar effects may be occurring in some of the specimens we examined. Total $\mathrm{Hg}$ content of freshwater mussels transplanted to the vicinity of a Superfund site on the Sudbury River was correlated with growth rates (Beckvar et al. 2000). However, our maximum total $\mathrm{Hg}$ and $\mathrm{MeHg}$ concentrations (53 and 32 $\mathrm{ng} / \mathrm{g}$, respectively) were considerably lower than even their mean background concentrations (640 and $140 \mathrm{ng} / \mathrm{g} \mathrm{dw}$, respectively).

We did not detect PCBs in water or sediments; thus, the low detection rates in mussels may reflect a lack of recent availability in the area. Unionid mussels placed in contaminated sections of the Detroit River accumulated PCBs in just three weeks (Kauss and Hamdy 1985), 
so the mussels we examined should have contained PCBs if they were present and readily available. Higher concentrations and increased prevalence of PCBs in mussels at MSD might be due to the site's proximity to the town of Grafton, Illinois, where municipal inputs of PCBs (e.g., transformer leaks/fires, waste water treatment plant discharge, etc.) into waterways may have existed.

Renaud et al. (2004) observed total PCB concentrations as high as $20 \mathrm{ng} / \mathrm{g}$ ww (converted from dw) in the unionid Elliptio complanata from the Rideau River in Ontario. This species accumulated mean total PCB concentrations of 140 to $543 \mathrm{ng} / \mathrm{g}$ ww after being placed at more highly-contaminated contaminated locations in the Detroit River (Kauss and Hamdy 1985). Koenig and Metcalfe (1990) reported mean total PCB concentrations of as high as $\sim 61 \mathrm{ng} /$ gww in Elliptio complanata transplanted into the Otonabee River in Ontario. Thus, the maximum summed concentration of PCB congeners we observed $(100 \mathrm{ng} / \mathrm{g} \mathrm{ww})$ indicated that mussels from below the confluence of these
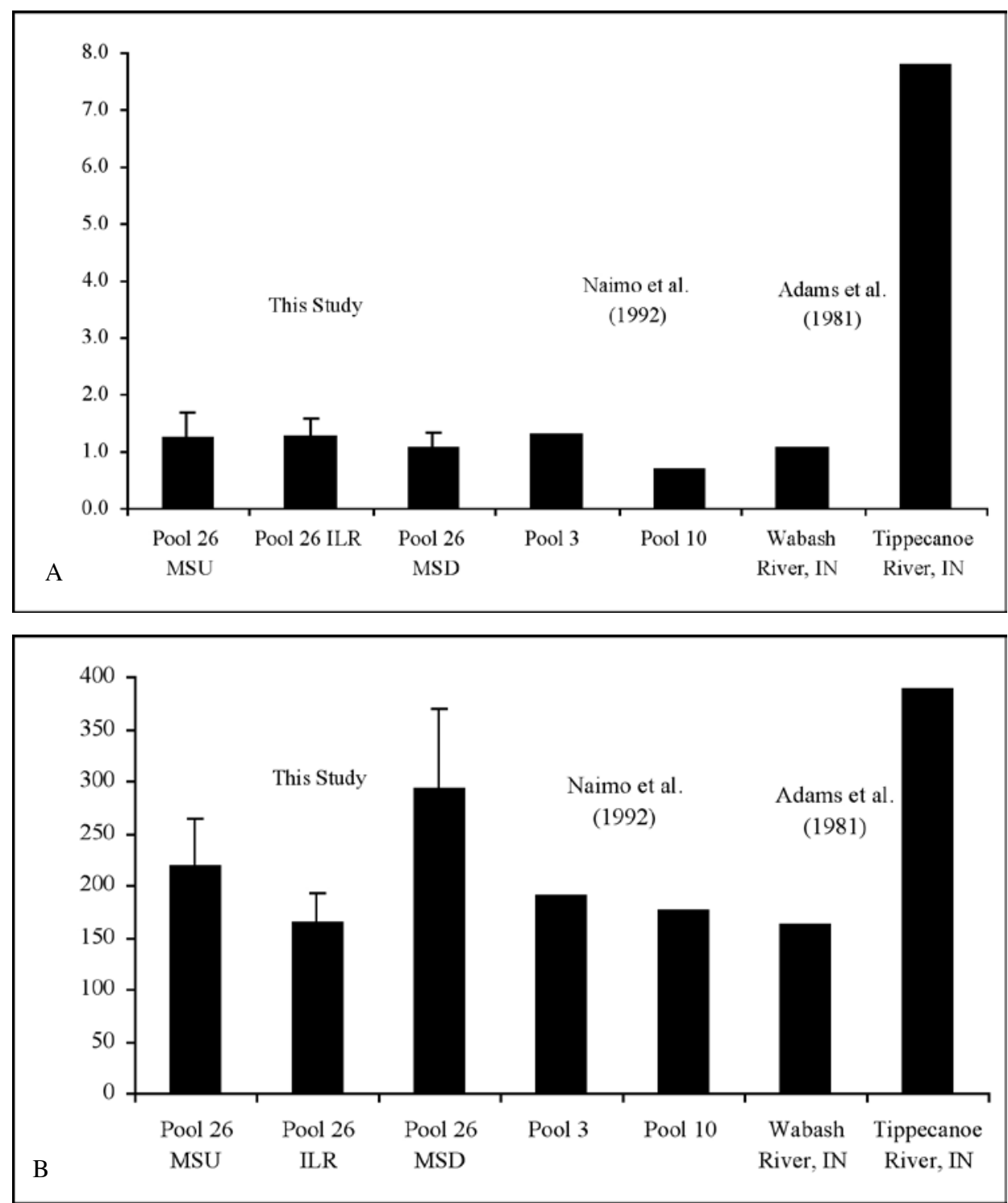

Figure 2. Whole body A) cadmium and B) zinc concentrations in Amblema plicata from Mississippi River Pool 26 (this study), Pools 3 and 10 (Naimo et al. 1992), and a transplant study (Adams et al. 1981) in Indiana. 
rivers might accumulate relatively high concentrations of PCBs. Although comparisons with published values are informative, caution must be used as detection limits and the suite of individual congeners measured may differ between studies.

Dichlordiphenyltrichloroethane and its metabolites were the organochlorine pesticides present in the highest concentrations in mussels from Rideau River in Ontario (Renaud et al. 2004). In contrast, with the exception of DDT in one specimen from MSD, neither DDT, DDD, nor DDE were detected in the mussels examined in our study. The $\beta$ and $\delta$ isomers of hexachlorocyclohexane were the most frequently detected organochlorine pesticides in our study. Renaud et al. (2004) detected $\beta-\mathrm{HCH}$ in E. complanata at a maximum concentration of $0.6 \mathrm{ng} / \mathrm{g} \mathrm{dw}$. By comparison, the maximum $\beta-\mathrm{HCH}$ value observed in our study (103.5 ng/g $\mathrm{ww}=601.7 \mathrm{ng} / \mathrm{g} \mathrm{dw}$ ) was considerably greater than observed in that observed by Renaud et al. (2004).

Our findings, when coupled with the results of the few previous studies examining the adverse effect levels of contaminant exposure in mussels, suggest that mussels from near the confluence of the Mississippi and Illinois Rivers had elevated exposure to several environmental contaminants, notably $\mathrm{MeHg}, \mathrm{Zn}, \beta-\mathrm{HCH}$ and PCBs (downstream of confluence). Based on these findings, studies examining the health and productivity of unionid mussels from this area appear warranted.
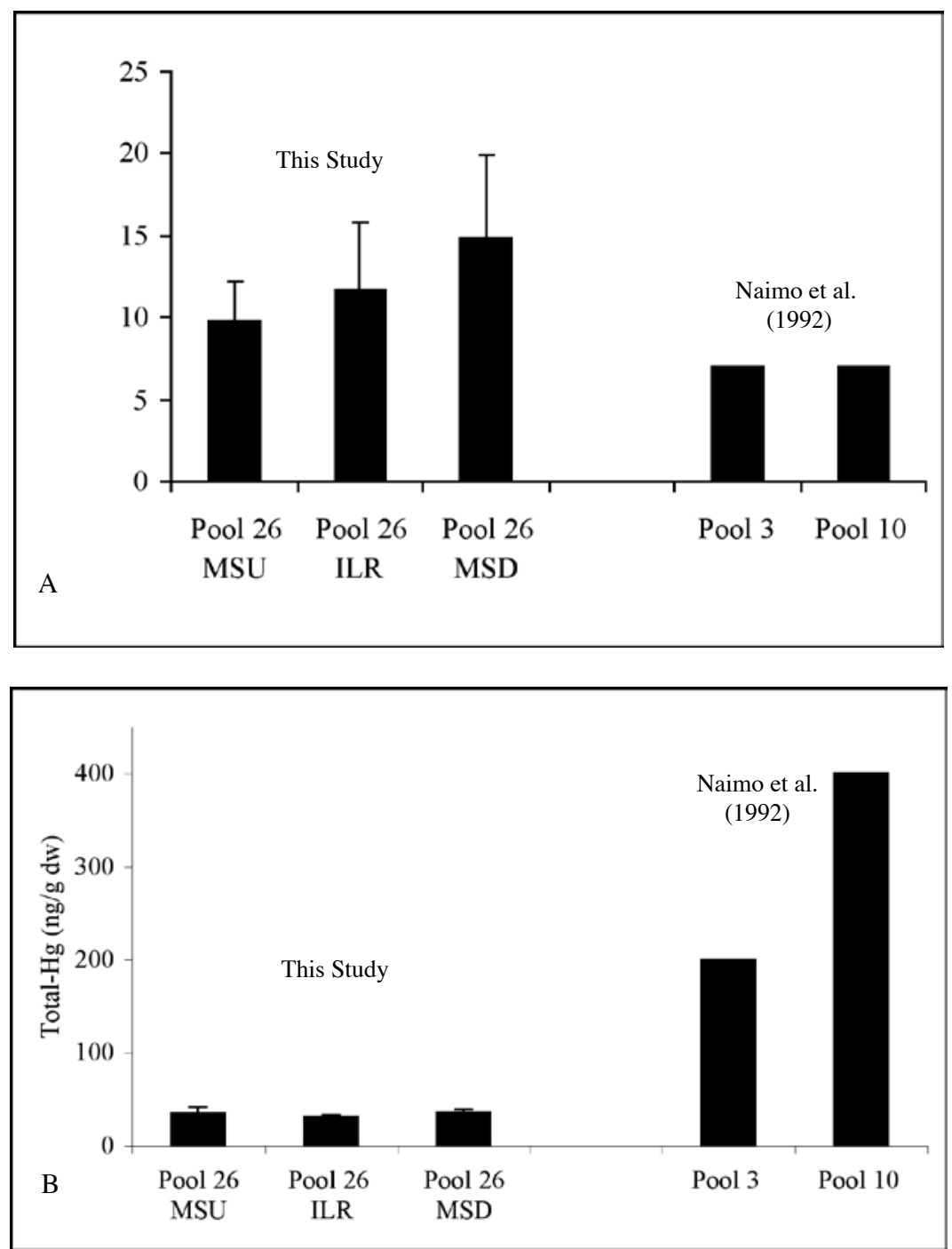

Figure 3. Whole body A) copper and B) total mercury concentrations in Amblema plicata from Mississippi River Pool 26 (this study) and Pools 3 and 10 (Naimo et al. 1992). 


\section{LITERATURE CITED}

Adams, T.G., G.J. Atchison, and R.J. Vetter. 1981. The use of the three-ridge clam (Amblema perplicata) to monitor trace metal contamination. Hydrobiologia 83:67-72.

Ahlstedt, S.A., and J.D. Tuberville. 1997. Quantitative reassessment of the freshwater mussel fauna in the Clinch and Powell rivers, Tennessee and Virginia. Pages 71-77 in K.S. Cummings, A.C. Buchanan, C.A. Mayer, and T.J. Naimo, eds., Conservation and management of freshwater mussels II, Proceedings of the Upper Mississippi River Conservation Committee symposium, October 16-18, 1995. St. Louis, MO.

Allen, H.J., W.T. Waller, M.F. Acevedo, E.L. Morgan, K.L. Dickson, and J.H. Kennedy. 1996. A minimally invasive technique to monitor valve-movement behavior in bivalves. Environmental Technology 17:501-507.

American Society for Testing and Materials (ASTM). 2001. Standard guide for conducting in-situ field bioassays with marine, estuarine, and freshwater bivalves, (ASTM E 2122-01, West Conshohocken, PA. Pages 1546-1575.

Beckvar, N., S. Salazar, M. Salazar, and K. Finkelstein. 2000. An in situ assessment of mercury contamination in the Sudbury River, Massachusetts, using transplanted freshwater mussels (Elliptio complanata). Canadian Journal of Fisheries and Aquatic Sciences 57: 1103-1112.

Belanger, S.E., J.L. Farris, D.S. Cherry, and J. Cairns, Jr. 1986. Growth of Asiatic clams (Corbicula sp.) during and after long-term zinc exposure in field-located and laboratory artificial streams. Archives of Environmental Contamination and Toxicology 15:427-434.

Belanger, S.E., J.L. Farris, D.S. Cherry, and J. Cairns, Jr. 1990. Validation of Corbicula growth as a stress response to copper in artificial and natural streams. Canadian Journal of Fisheries and Aquatic Sciences 47:904-914.
Berry, W.J., D.J. Hansen, J.D. Mahony, and D.L. Robson. 1996. Predicting the toxicity of metal-spiked laboratory sediments using acidvolatile sulfide and interstitial water normalizations. Environmental Toxicology and Chemistry 15(12):2067-2079.

Black, M.C. 1997. Biomarker assessment of environmental contamination with freshwater mussels. Journal of Shellfish Research 16:323.

Blodgett, K.D., and R.E. Sparks. 1987. A summary of freshwater mussel sampling in the Mississippi River Pool 15, Upper Mississippi River. Report to Illinois Department of Conservation. Illinois Natural History Survey Aquatic Biology Section Technical Report 87/16. 11pp.

Bogan, A.E. 1993. Freshwater bivalve extinctions (Mollusca:Unionidae): a search for causes. American Zoologist 33:599-609.

Cherry, D.S., J.H. Van Hassel, J.L. Farris, D.J. Soucek, and R.J. Neves. 2002. Site-specific derivation of the acute copper criteria for the Clinch River, Virginia. Human and Ecological Risk Assessment 8:591-601.

Cope, G.W., R.B. Bringolf, D.B. Buchwalter, T.J. Newton, C.G. Ingersoll, N. Wang, T. Augspurger, J.F. Dwyer, C.M. Barnhart, R.J. Neves, and E. Hammer. 2008. Differential exposure, duration, and sensitivity of unionoidean bivalve life stages to environmental contaminants. Journal of the North American Benthological Society 27:451-462.

Cummings, K.S., and C.A. Mayer. 1992. Field guide to freshwater mussels of the Midwest. Illinois Natural History Survey Manual 5. 194 pp.

DiToro, D.M., J.D. Mahony, D.J. Hansen, and K.J. Scott. 1990. Toxicity of cadmium in sediments: the role of acid-volatile sulfide. Environmental Toxicology and Chemistry 9:1487-1502. 
Doherty, F.G. 1990. The Asiatic clam, Corbicula spp., as a biological monitor in freshwater environments. Environmental Monitoring and Assessment 15:143-181.

Ecological Specialists, Inc. (ESI). 1999. Final Report Mississippi River Pool 26 Unionid Survey prepared for Great Rivers Land Preservation Association, Inc. Alton, IL. 31 pp. and appendices.

Farris, J.L., S.E. Belanger, D.S. Cherry, and J. Cairns, Jr. 1989. Cellulolytic activity as a novel approach to assess long-term zinc toxicity to Corbicula. Water Research 23:1275-1283.

Foster, R.B., and J.M. Bates. 1978. Use of freshwater mussels to monitor point source industrial discharges. Environmental Science and Technology 12:958-962.

Garbarino, J.R., H.C. Hayes, D.A. Roth, R.C. Antweiler, T.I. Brinton, and H.E. Taylor. 1995. Heavy metals in the Mississippi River. Pages 1987-1992 in R.H. Meade, ed. Contaminants in the Mississippi River. USGS Circular 1133, Reston, VA.

Grabowski, L.A., J.L.J. Houpis, W.I. Woods, and K.A. Johnson. 2001. Seasonal bioavailability of sediment-associated heavy metals along the Mississippi river floodplain. Chemosophere 45:643-651.

Groschen, G.E., M.A. Harris, R.B. King, P.J. Terrio, and K.L. Warner. 2000. Water quality in the Lower Illinois River basin: Illinois, 1995-98. US Geological Survey Circular 1209. $36 \mathrm{pp}$.

Hinch, S.G., and LK.A. Stephenson. 1987. Size- and age-specific patterns of trace metal concentrations in freshwater clams from an acid-sensitive and a circumneutral lake. Canadian Journal of Zoology 65:2436-2442.

Indorante, S.J, L.R. Follmer, R.D. Hammer, and P.G. Koenig. 1990. Particle-size analysis by a modified pipette procedure. Soil Science Society of America Journal 54:560-563.
Jacobson, P.J., J.L. Farris, R.J. Neves, and D.S. Cherry. 1993. Juvenile mussel (Bivalvia:Unionidae) responses to acute toxicity testing with copper. Environmental Toxicology and Chemistry 12:879-883.

Jacobson, P.J., J.L. Farris, R.J. Neves, and D.S. Cherry. 1997. Sensitivity of glochidial stages of freshwater mussels to copper. Environmental Toxicology and Chemistry 16:2384-2392. Kauss, P.B., and Y.S. Hamdy. 1985. Biological monitoring of organochlorine contaminants in the St. Clair and Detroit rivers using introduced clams (Elliptio complanatus). Journal of Great Lakes Research 11:247-263.

Koenig, B.G., and C.D. Metcalfe. 1990. The distribution of PCB congeners in bivalves, $E l$ liptio complanata, introduced in the Otonabee River Peterborough, Ontario. Chemosphere 21:1441-1449.

Levengood, J.M. 2003. Cadmium and lead in Mallards (Anas platyrhynchos) and Wood Ducks(Aix sponsa) using the Illinois River (USA). Environmental Pollution 122:177-181.

Lydeard, C, R.H. Cowie, W.F. Ponder, A.E. Bogan, P. Bouchet, S.A. Clark, K.S. Cummings, T.J. Frest, O. Gargominy, D.G. Herbert, R. Hershler, K.E. Perez, B. Roth, M.B. Seddon, E.E. Strong, and F.G. Thompson. 2004. The global decline of nonmarine mollusks. BioScience 54:321-330.

Metcalfe-Smith, J.L., R.H. Green, and L.C. Grapentine. 1996. Influence of biological factors inconcentrations of metals in the tissues of freshwater mussels (Elliptio complanata and Lampsilis radiata radiata) from the St. Lawrence River. Canadian Journal of Fisheries and Aquatic Sciences 53:205-219.

Miller, A.C., B.S. Payne, and F.M. Burns. 1997. Measures to minimize harm to Lampsilis higginsi caused by passage of commercial navigation vessels in the Upper Mississippi River. Technical Report EL-97-12. U.S. Army Corps of Engineers Waterways Experiment Station, Vicksburg, MS. 39 pp. 
Moore, H.J. 1971. The structure of the lateral frontal cirri on the gills of certain lamellibranch molluscs and their role in suspension feeding. Marine Biology 11:23-27.

Naimo, T.J., D.L. Waller, and L.E. HollandBartels. 1992. Heavy Metals in the threeridge mussel Amblema plicata plicata (Say, 1817) in the Upper Mississippi River. Journal of Freshwater Ecology 7:2:209-217.

Naimo, T.J. 1995. A review of the effects of heavy metals on freshwater mussels. Ecotoxicology 4:341-362.

Naimo, T.J., E.D. Damschen, R.G. Rada, and E.M. Monroe. 1998. Nonlethal evaluation of the physiological health of unionid mussels: methods for biopsy and glycogen analysis. Journal of the North American Benthological Society 17:121-128.

Newton, T.J., E.M. Monroe, E. Kenyon, S. Gutreuter, K.I. Welke, and P.A. Thiel. 2001. Evaluation of relocation of unionid mussels into artificial ponds. Journal of the North American Benthological Society 20:468-485.

Paquin, P.R., J.W. Gorsuch, S. Apte, G.E. Batley, K.C. Bowles, P.G.C. Campbell, C.G. Delos, D.M. Di Toro, R.L. Dwyer, F. Galvez, R.W. Gensemer, G.G. Goss, C. Hogstrand, C.R. Janssen, J.C. McGeer, R.B. Naddy, R.C. Playle, R.C. Santore, U. Schneider, W.A. Stubblefield, C.M. Wood, and K.B. Wu. 2002. The biotic ligand model: a historical review. Comparative Biochemistry and Physiology Part C 133:3-35.

Paquin, P.R., K. Farley, R.C. Santore, C.D. Kavvadas, K.G. Mooney, R.P. Winfield, K.B. Wu, And D.M. DiToro. 2003. Metals in aquatic environments: a review of exposure, bioaccumulation, and toxicity models. Society of Environmental Toxicology and Chemistry (SETAC), Pensacola, Florida.
Renaud, C.B., A.L. Martel, K.L.E. Kaiser, and M.E. Comba. 2004. A comparison of organochlorine contaminant levels in the zebra mussel, Dreissena polymorpha, versus its unionid attachment, Elliptio complanata, in the Rideau River, Ontario. Water Quality Research Journal of Canada 39:83-92.

Salazar, S.M., N. Beckvar, M.H. Salazar, and K. Finkelstein K. 1995. An in situ assessment of mercury contamination in the Sudbury River, Massachusetts, using bioaccumulation and growth in transplanted freshwater mussels. NOAA Technical Report. Submitted to U.S. Environmental Protection Agency, Massachusetts Superfund Program Region 1, Boston, MA.

Schmitt, C.J., D.E. Tillitt, V.S. Blazer, T.S. Gross, N.D. Denslow, T.M. Bartish, and B.S. Arnold. 2002. Project summary, discussion, and recommendations. Pages 171-198 in C.J. Schmitt, ed. Biomonitoring of environmental status and trends (BEST) programs: environmental contaminants and their effects on fish in the Mississippi River basin. USGS, Biol. Sci. Rpt. 2002-0004. 241 pp.

Shade, C.W., and R.J.M. Hudson. 2005. Determination of $\mathrm{MeHg}$ in environmental sample matrices using Hg-Thiourea Complex Ion Chromatography with on-line cold vapor generation and atomic fluorescence spectrometric detection (HgTU/IC-CVAFS). Environmental Science and Technology 39:4974-4982.

Smith, J.G., and J.J. Beauchamp. 2000. Evaluation of caging designs and a fingernail clam for use in an in situ bioassay. Environmental Monitoring and Assessment 62:205-230.

Starrett, WC. 1971. A survey of the mussels (Unionacea) of the Illinois River: a polluted stream. Illinois Natural History Survey Bulletin 30:267-403.

Strong, C.R, and S.N. Luoma. 1981. Variations in the correlation of body size with concentrations of $\mathrm{Cu}$ and $\mathrm{Ag}$ in the bivalve Macoma balthica. Canadian Journal of Fisheries and Aquatic Sciences 38:1059-1064. 
U.S. Environmental Protection Agency

(USEPA). 1991. Methods for determination of metals in environmental samples. EPA 600/491/010, Office of Research and Development, Cincinnati, $\mathrm{OH}$.

U.S. Environmental Protection Agency (USEPA). 1999. Test methods for evaluating solid waste, physical/chemical methods, Third ed. Automated soxhlet extraction (Method 3541), gel-permeation clean-up (Method 3640A), and organochlorine pesticide, halowaxes, and PCBs as Aroclors by gas chromatography: capillary column technique (Method 8081). Microwave assisted digestion of siliceous and organically based matrices. EPASW-846.3-3A U.S. Environmental Protection. Agency, Washington, DC, USA.

Vaughn, C.C., and C.C. Hakenkamp. 2001. The functional role of burrowing bivalves in freshwater ecosystems. Freshwater Biology 46:1431-1446.

Whitney, S.D., K.D. Blodgett, and R.E. Sparks. 1997. A Comprehensive mussel survey of the Illinois River, 1993-95.Illinois Natural History Survey Draft Technical Report. 32 pp. + appendices.

Williams, J.D., M.L. Warren, Jr., K.S. Cummings, J.L. Harris, and R.J. Neves. 1993. Conservation status of freshwater mussels of the United States and Canada. Fisheries 18:6-22. 

University of Illinois,

Institute for Natural Resource Sustainability,

William Shilts, Executive Director

Illinois Natural History Survey

Brian D. Anderson, Director

I-Building

1816 South Oak Street

Champaign, Illinois 61820

217-333-6880 